\title{
To What Extent Is the Institutional Environment Responsible for Worldwide Differences in Economic Development
}

\author{
Mariusz Próchniak ${ }^{1}$
}

\begin{abstract}
This study aims to assess to what extent the institutional environment is responsible for worldwide differences in economic development. To answer this question, a new concept of the institutions-augmented Solow model is constructed. The analysis covers 153 countries and the period 1994-2009. The empirical analysis confirms a large positive impact of the quality of the institutional environment on the level of economic development. This positive link has been evidenced for all six of the employed institutional indicators (although nonlinearities are present in some cases). Our own concept of the institutions-augmented Solow model fits the empirical data very well. It turns out that differences in physical capital, human capital and the institutional environment (which is measured by the governance indicator) explain approximately $75 \%$ of the differences in economic development among the countries of the world. According to the institutions-augmented Solow model, the production function that is consistent with the empirical data is $Y=K^{0.372} \mathrm{H}^{0.315} \mathrm{~L}^{0.313} \mathrm{Q}^{0.705}$, where $\mathrm{K}$ is the physical capital, $\mathrm{H}$ is the human capital, $\mathrm{L}$ is the labor and $\mathrm{Q}$ represents the institutional indicator.
\end{abstract}

KEY WORDS: $\quad$ economic development; institutions; economic growth

JEL Classification: $\quad$ 040, 043

${ }^{1}$ Warsaw School of Economics, Poland

\section{Introduction}

The economic growth and economic development of countries both depend on many factors. Using the most common classification, we can divide these factors into two groups: the demand-side determinants and the supply-side determinants. The first group encompasses the variables that create GDP according to the following equation: $Y=C+I+G+N X$, where $C$ denotes consumption, $I$ denotes investments, $G$ deㅁ notes government spending on goods and services,

Correspondence concerning this article should be addressed to: Mariusz Próchniak, Warsaw School of Economics. Al. Niepodleglosci 162, Warszawa 02-554 Poland. e-mail:mproch@sgh.waw.pl and NX denotes the net exports. Except for consumption, which is not an autonomous factor because of its dependence on output, the remaining variables can be regarded as economic growth determinants, as confirmed by the Keynesian model. The second group of factors includes the supply-side determinants that are directly related to the macroeconomic production function. The most common production function takes the form $Y=F(K, H, L, A)$, where $K$ denotes the physical capital, $H$ denotes the human capital, $L$ denotes the labor and $A$ denotes the technology. These variables influence the potential output and are economic growth determinants in the classical model. Of course, both demand-side and supplyside variables can be more disaggregated and include 
inter alia various types of investments or government spending or many more types of capital.

The above factors that influence economic growth and economic development can be called "direct" factors because they immediately transform inputs into outputs. These factors are analyzed in the theoretical models of economic growth that show what the determinants of long-run growth and the development level are.

However, the macroeconomic performances of countries do not depend exclusively on these direct determinants. There are also "deep" factors of production that have an impact on the "direct" factors, and in this way, the deep factors affect the process of economic growth and development. "Deep" determinants are institutions that provide the background for the interactions between measurable factor inputs and the level of output.

The aim of this paper is twofold. First, we would like to choose the best concept of the index that measures the institutional environment. Such an index should fit the empirical data very well and be useful in explaining the income differences of all of the countries in the world. We can select either one qualitative variable that is compiled by an international organization or a mix of such variables. Second, we would like to quantify the impact of institutions on countries' development levels.

Most theoretical models of economic growth do not explicitly include institutions as growth determinants. Indeed, the macroeconomic production function includes only those quantitative variables that directly influence the level of output.

In this paper, we would like to answer the title question, which is the major research hypothesis: "To what extent the institutional environment is responsible for worldwide differences in economic development". We do not intend to analyze whether institutions have an impact on economic development because the answer is obvious; our goal is to quantify their impact, i.e., to measure what part of the variance in economic development can be attributed to a different institutional environment. We measure the level of economic development by GDP per capita at purchasing power parity (PPP). Our study covers 153 countries.

The analysis is based on our own concept of the institutions-augmented Solow model. The standard Solow model (1956) includes only one type of capi- tal according to the following production function: $Y=F(K, L, A)$. Mankiw, Romer and Weil (1992) extended the Solow model by introducing another type of capital: human capital; to that end, they employed the following production function: $Y=F(K, H, L, A)$. Nonneman and Vanhoudt (1996) further extended the Solow model by adding more types of capital. They analyzed the model with three types of capital: physical capital, human capital and technological know-how.

In our opinion, the value added of introducing more and more types of capital is diminishing. This decrease is occurring because economic growth and economic development depend not only on "direct" factors but also on "deep" determinants that are related to the institutional environment. Thus, we propose the extension of the macroeconomic production function in the way similar to the method of Nonneman and Vanhoudt, but we argue that institutions should be included as new factors of production. Thus, we use the following production function: $F(K$, $H, Q, L, A)$, where $Q$ is the qualitative index that measures the institutional environment of a country. Our aim is to choose the best concept of such an index and to estimate the impact of institutions on the level of economic development.

The paper consists of seven sections. In section 2, we present a literature review that describes some other empirical studies on the institutions-growth nexus. Section 3 refers to the methodology that provides a concise description of the Mankiw-Romer-Weil model and the institutions-augmented Solow model. Section 4 describes the data that were used. The results of the analysis are presented in sections 5 and 6 . Section 7 concludes.

\section{A review of the literature on the institutions-growth nexus}

There is no unique method for measuring institutions. For example, Sulejewicz (2009) provides many different concepts of institutions. However, many of these concepts cannot be included in empirical studies that incorporate econometric techniques because some types of institutions are very hard to quantify. Thus, in empirical studies, researchers can only use a limited number of qualitative indicators that measure a given aspect of the institutional environment. Most of these indicators are related with economic freedom, the level 

linear relationship with economic growth. The highest GDP dynamics are recorded by those countries that have a moderate level of democracy. Rivera-Batiz (2002) tests the democracy index (i.e., the political rights index compiled by the Freedom House) as well as the quality of governance indicator compiled by Hall and Jones. This research, which was conducted for 59 countries in the years 1960-1990, confirms that the quality of governance positively and significantly affects the economic growth, whereas democracy only stimulates economic growth when it is related with improved governance. Leblang (1997) analyzes the democracy index according to Gurr for 91 countries during 1960-1989, and the results confirm that the initial level of democracy positively and significantly influences the GDP dynamics. Feng (1997) uses several institutional variables, such as the democracy level according to Gurr, the democracy level according to Bollen and the probabilities of government changes. This analysis covers 96 countries in the years 1960-1980, and the results suggest that democracy has a twofold impact on economic growth: the direct impact is negative, whereas an indirect impact is positive because of influence on the probability of government changes. Moreover, important regular government changes favorably affect macroeconomic performance, whereas irregular changes have the opposite effect. Thus, democracy indirectly influences the GDP growth because it increases the probability of important regular government changes and lowers the probability of irregular changes. Barro (1996) focuses on the political rights index compiled by Gastil and Bollen as well as on the rule-of-law index. The data for approximately 100 countries and the period 1960-1994 indicate that political freedom is nonlinearly related with economic growth: given a low level of political rights, extending political rights stimulates economic growth; however, when a specified level of democracy has been achieved, any further extension of political rights negatively affects the growth of output. In contrast, the rule-of-law index is positively and significantly correlated with the economic growth. Próchniak and Witkowski (2012a; 2012b; 2013) analyze the impact of economic freedom and the level of democracy on GDP growth using an innovative method of Bayesian model averaging; they find that economic freedom is one of the main growth drivers in the EU.
In addition, there are several studies that verify the relationship between political stability and economic growth. For example, Asteriou and Siriopoulos (2000) analyze data for Greece during 1960-1995; Asteriou and Price (2001) focus on the UK in the years 1961-1997; and Fosu (2002) examines 31 Sub-Saharan African countries in the period 1960-1986. All of these studies confirm the existence of the negative relationship between political instability and economic development. Although the studies differ in terms of the variables used (inter alia, terrorist attacks, political strikes, coups détats, political assassinations, the Falkland war and the Persian Gulf War), the results clearly indicate that political stability is conducive to economic development. Similarly, Chen and Feng (1996) analyze the probability of changing the regime (which is calculated based on the logit model), economic freedom and the number of political assassinations using a sample of 88 countries during 1974-1990. According to their work, a higher probability of changing the regime, a greater number of political assassinations and a lower scope of economic freedom are factors that hamper economic growth. However, Wu and Davis (1999) achieve opposite findings: they analyze the political stability index (compiled based on political rights and civil liberties from the work of Gastil) and apply it to approximately 100 countries during 1975-1992. They conclude that for a given level of economic freedom, the rate of economic growth does not depend on the level of political freedom. In an analysis that covers 105 countries in the period 1960-1989, Durham (1999) finds that the number of political parties in the government is not correlated with economic growth.

Some institutions are very hard to measure, and they require descriptive analysis rather than quantitative (formal) models. For example, Hunt (2012a) analyzes the relationship between trust within a society and economic growth and shows that trust-promoting, societal-level moral codes promote productivity and economic growth (see also Foss (2012) and Hunt (2012b) for further discussion).

In summation, the empirical evidence confirms an enormous impact of institutions on economic growth. Thus, when analyzing the sources of income-level differences between countries from different parts of the world, we have to include institutional measures. This requirement is why we extend the Solow model to account for institutions. 


\section{Theoretical background and the methodology}

In this part of the paper, we describe the determinants of economic development by referring to the family of Solow models. We begin with the Solow model that is extended for human capital (i.e., the Mankiw-RomerWeil model). Then, we show a further augmentation of the Solow model that incorporates a slightly modified version of the model proposed by Nonneman and Vanhoudt. It is our own concept, and we call it the institutions-augmented Solow model. This model constitutes the main background for our empirical research.

\section{(a) The Mankiw-Romer-Weil model}

Let $F$ be the production function. The factors of production are as follows: physical capital $K(t)$, human capital $H(t)$ and effective labor $A(t) L(t)$, which is the product of the level of technology (knowledge) $A(t)$ and the size of the population (labor force) $L(t)$ :

$$
F(K(t), H(t), A(t) L(t))
$$

The production function exhibits constant returns to all three of the inputs (i.e., physical capital, human capital and effective labor) and the diminishing marginal product of both physical and human capital. One of the functions that satisfy these properties is the CobbDouglas production function:

$F(K(t), H(t), A(t) L(t))=K(t)^{\alpha} H(t)^{\beta}[A(t) L(t)]^{1-\alpha-\beta},(2)$

where $\alpha>0, \beta>0, \alpha+\beta<1$. The output may be devoted to consumption, the accumulation of physical capital, or the accumulation of human capital. The level of technology and the size of the population both grow at constant exogenous rates that are equal to $a$ and $n$, respectively:

$\frac{\dot{A}(t)}{A(t)}=a \quad$ and $\quad \frac{\dot{L}(t)}{L(t)}=n$.

The increase of capital equals the investments minus the depreciation. Let $s_{K}$ be the investment rate in physical capital (i.e., the savings rate) and let $s_{H}$ be the investment rate in human capital. Both types of capital depreciate at the same constant rate $\delta$. Hence, the respective time paths of physical and human capital are as follows:

$$
\begin{aligned}
& \dot{K}(t)=s_{K} F(K(t), H(t), A(t) L(t))-\delta K(t), \\
& \dot{H}(t)=s_{H} F(K(t), H(t), A(t) L(t))-\delta H(t) .
\end{aligned}
$$

The analysis of the economy is carried out for the capital and the output per unit of effective labor, which are denoted by $k(t), h(t)$ and $f(k(t), h(t))$ :

$$
\begin{aligned}
& k \equiv \frac{K}{A L} ; h \equiv \frac{H}{A L} ; y \equiv f(k, h) \equiv \frac{F(K, H, A L)}{A L}\{= \\
& \left.=F\left(\frac{K}{A L}, \frac{H}{A L}, \frac{A L}{A L}\right)=F(k, h, 1)=f(k, h)\right\} .
\end{aligned}
$$

To find equations that describe the behavior of the economy, we differentiate the definitions of $k$ and $h$ (given by (6)) with respect to time. Then, we apply formulas (3) - (6). Assuming that the production function is of the Cobb-Douglas form $y=f(k, h)=k^{a} h^{\beta}$, we finally obtain

$\dot{k}=s_{K} y-(n+a+\delta) k=s_{K} k^{\alpha} h^{\beta}-(n+a+\delta) k$,

$\dot{h}=s_{H} y-(n+a+\delta) h=s_{H} k^{\alpha} h^{\beta}-(n+a+\delta) h$.

The above equations are the basic equations that describe the dynamics of the economy in the MankiwRomer-Weil model. The increase of capital per unit of effective labor equals the real investments $\left(s_{K} y\right.$ or $\left.s_{H} y\right)$ minus the replacement investments $((n+a+\delta) k$ or $(n+a+\delta) h)$.

Based on the above formulas, we can graphically show the dynamics of the economy and the steadystate, as in Figure 1.

The steady-state occurs at the point of intersection between $d k / d t=0$ and $d h / d t=0$. At this point, both types of capital and the output per unit of effective labor are all constant. The steady-state is stable: regardless of the initial level of capital (unless it is zero), the economy tends to the steady-state (the changes of $k$ and $h$ are marked by arrows).

Because in the steady-state both physical and human capital per unit of effective labor are constant, by setting (7) and (8) to zero we can calculate the amount of physical capital $\left(k^{*}\right)$ and human capital $\left(h^{*}\right)$ in the steady-state. By using the production function $y=k^{\alpha} h^{\beta}$ and applying some mathematics, we finally obtain the steady-state level of output $\left(y^{*}\right)$ : 


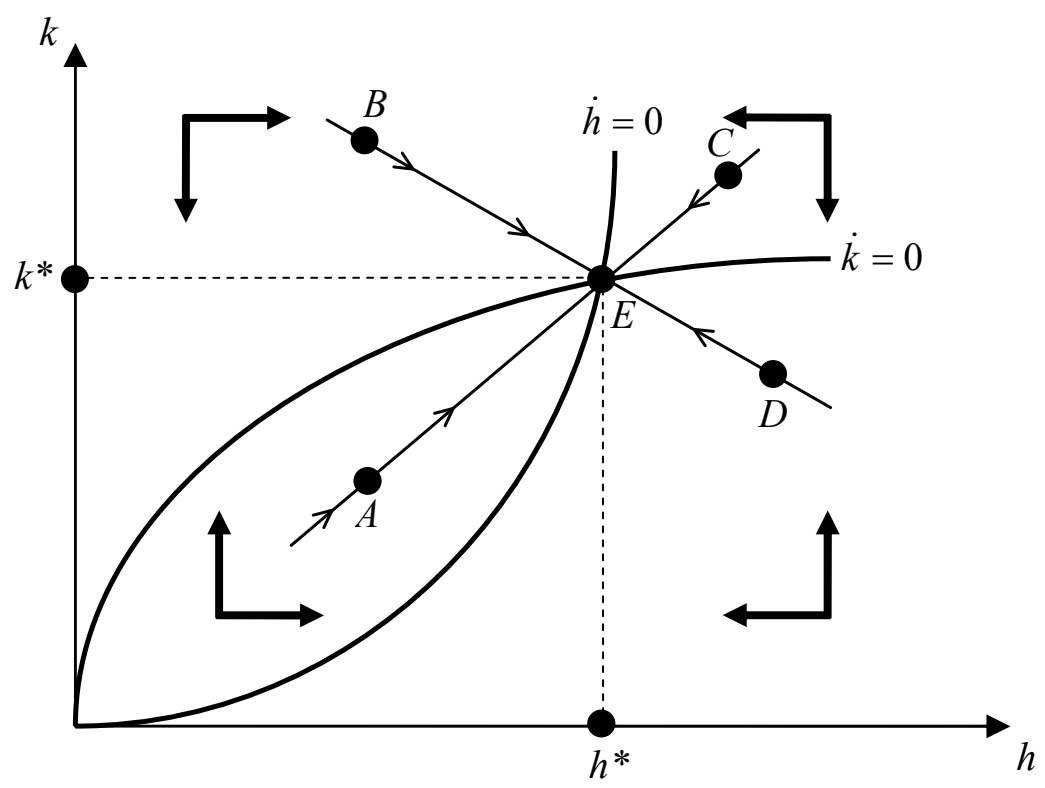

Figure 1. The transition period and the steady-state in the Mankiw-Romer-Weil model

$k^{*}=\left(\frac{s_{K}^{1-\beta} s_{H}^{\beta}}{n+a+\delta}\right)^{\frac{1}{1-\alpha-\beta}} ; h^{*}=\left(\frac{s_{H}^{1-\alpha} s_{K}^{\alpha}}{n+a+\delta}\right)^{\frac{1}{1-\alpha-\beta}} ;$

$y^{*}=\left(\frac{s_{K}}{n+a+\delta}\right)^{\frac{\alpha}{1-\alpha-\beta}}\left(\frac{s_{H}}{n+a+\delta}\right)^{\frac{\beta}{1-\alpha-\beta}}$.

Because the output per unit of effective labor $(y)$ is equal to the per capita GDP $(Y / L)$ divided by the level of technology $(A)$, from (9) we can calculate the steady-state level of per capita output:

$\frac{Y}{L}=A\left(\frac{s_{K}}{n+a+\delta}\right)^{\frac{\alpha}{1-\alpha-\beta}}\left(\frac{s_{H}}{n+a+\delta}\right)^{\frac{\beta}{1-\alpha-\beta}}$.

Equation (10) shows the determinants of GDP per capita in the long-run equilibrium according to the Mankiw-Romer-Weil model. Apart from the variables $A$ (the level of technology), $a$ (the technical progress) and $\delta$ (the depreciation rate), which are very hard to measure, the per capita income depends on the savings rate, the investment rate in human capital and the population growth. The relationship between the level of economic development and the accumulation of physical and human capital is positive, whereas the relationship between the level of economic development and the growth rate of the population is negative. Thus, rich countries should record higher investment rates in both types of capital and slower population growth than poor countries. After taking logarithms, Formula (10) can be estimated as the following linear regression equation:

$\ln \left(\frac{Y}{L}\right)=\ln A+\frac{\alpha}{1-\alpha-\beta} \ln s_{K}+$

$+\frac{\beta}{1-\alpha-\beta} \ln s_{H}-\frac{\alpha+\beta}{1-\alpha-\beta} \ln (n+a+\delta)$,

where $\ln A$ is a constant and $\ln s_{K^{\prime}}, \ln s_{H}$ and $\ln (n+a+\delta)$ are explanatory variables.

It is worth noticing that if we substitute zeros for $H$, $h, s_{H}$ and $\beta$, then the above calculations are also valid for the standard Solow model. Equation (11), which describes the determinants of the income level in the steady-state for the basic Solow model, takes the form

$\ln \left(\frac{Y}{L}\right)=\ln A+\frac{\alpha}{1-\alpha} \ln s_{K}-\frac{\alpha}{1-\alpha} \ln (n+a+\delta)$. 
The above formula indicates that in the basic Solow model, the GDP per capita in the steady-state depends inter alia on the savings rate (with which it has a positive relationship) and the growth rate of the population (with which it has a negative relationship). Equation (12) can also be estimated as a linear regression model, which allows us to find the production function's parameters.

\section{(b) The institutions-augmented Solow model}

Nonneman and Vanhoudt further extended the Solow model. They analyze the model with many inputs, each of which is a specified type of capital. The production function has the form

$Y=K_{1}^{\alpha_{1}} K_{2}^{\alpha_{2}} \ldots K_{m}^{\alpha_{m}}(A L)^{1-\sum_{i=1}^{m} \alpha_{i}}$,

where $m$ represents the number of capital goods that are factors of production. In the standard Solow model, which only has physical capital, $m=1$. The Mankiw-Romer-Weil model, which includes human capital, assumes that $m=2$. Nonneman and Vanhoudt in their empirical study analyze a model with three inputs $(m=3)$ : physical capital, human capital and technological know-how.

However, as we argued in the introduction, the value that is added by introducing more types of capital is diminishing. This decreasing return is because economic growth and economic development depend not only on "direct" factors but also on "deep" determinants that are related to the institutional environment. Thus, we propose an extension of the macroeconomic production function in a way that is similar to the extension of Nonneman and Vanhoudt, but we argue that institutions should be included as new factors of production and not as different types of capital. Thus, we propose the following production function:

$$
Y=K^{\alpha} H^{\beta}(A L)^{1-\alpha-\beta} Q^{\zeta},
$$

where $Q$ is the qualitative index that measures the institutional environments of countries. One difference between our proposition (14) and the neoclassical production function is that our production function exhibits constant returns to all of the quantitative (direct) inputs, i.e., physical capital, human capital and effective labor (the sum of the exponents is 1). The institutional index has a separate power of $\zeta$ because this variable refers to "deep" GDP determinants, which reveal an impact on direct GDP determinants. Thus, the exponent for the institutional variable should not be related to the rest of the exponents, which represent conventional inputs. If $\zeta \rightarrow 0$, the institutional factor tends to 1 and the output does not depend on the quality of institutions. In such a case, only measurable inputs determine the level of output.

Another issue is the behavior of $Q$. Both for simplicity and due to reality, we do not analyze the institutional indicator as a time variable. Contrary to the capital and labor, we assume that institutions are constant over time. In turn, the institutional environment does not fluctuate much from one year to another, unlike the remaining variables. Thus, the dynamics of the model will be analyzed only in $(k, h)$ space. This restriction is of course a simplified assumption, but it facilitates the analysis very much.

Returning to the mathematical analysis of the mod$\mathrm{el}$, the production function per unit of effective labor is $y=\frac{Y}{A L}=k^{\alpha} h^{\beta} Q^{\zeta}$.

The time paths for the physical and human capital are derived in the same way as equations (7) and (8), which yields the following:

$\dot{k}=s_{K} y-(n+a+\delta) k=s_{K} k^{\alpha} h^{\beta} Q^{\zeta}-(n+a+\delta) k$,

$\dot{h}=s_{H} y-(n+a+\delta) h=s_{H} k^{\alpha} h^{\beta} Q^{\zeta}-(n+a+\delta) h$.

Using a similar analysis as before, the respective stocks of physical capital, human capital and output per unit of effective labor in the steady-state are as follows:

$k^{*}=\left(\frac{s_{K}^{1-\beta} s_{H}^{\beta} Q^{\zeta}}{n+a+\delta}\right)^{\frac{1}{1-\alpha-\beta}}$,

$h^{*}=\left(\frac{s_{H}^{1-\alpha} s_{K}^{\alpha} Q^{\zeta}}{n+a+\delta}\right)^{\frac{1}{1-\alpha-\beta}}$,

$y^{*}=\left(\frac{s_{K}}{n+a+\delta}\right)^{\frac{\alpha}{1-\alpha-\beta}}\left(\frac{s_{H}}{n+a+\delta}\right)^{\frac{\beta}{1-\alpha-\beta}} Q^{\frac{\zeta}{1-\alpha-\beta}}$.

Equation (20) shows the determinants of GDP per capita in the long-run equilibrium according to the institutions-augmented Solow model. The per capita 
income depends on both standard factors and on institutions. The relationship between the quality of institutions and the level of economic development is positive, which implies that countries with higher institutional qualities should be more developed than those with poor institutional environments.

Equation (20) can be logarithmized (similarly to equation (9) for the Mankiw-Romer-Weil model). This process yields

$$
\begin{aligned}
& \ln \left(\frac{Y}{L}\right)=\ln A+\frac{\alpha}{1-\alpha-\beta} \ln s_{K}+\frac{\beta}{1-\alpha-\beta} \ln s_{H}+ \\
& -\frac{\alpha+\beta}{1-\alpha-\beta} \ln (n+a+\delta)+\frac{\zeta}{1-\alpha-\beta} \ln Q
\end{aligned}
$$

The above formula can be estimated as a linear regression equation, which allows us to verify and empirically quantify the impact of institutions on economic development. Some assumptions on the specification of the regression model and the methods of estimation have to be imposed. For example, Białowolski, Kuszewski and Witkowski (2010) assume that all of the macroeconomic relationships are linear.

The estimation of equations (11), (12) and (21) is presented in section 6 .

\section{Data}

Our analysis is entirely based on the family of Solow models. Thus, we empirically verify only those equations that can be derived from the theoretical analysis of the model, which is presented in section 3.

To analyze the determinants of economic development, we use equations (12), (11) and (21). The first formula represents the standard Solow model, the second formula is in line with the Mankiw-Romer-Weil model and the last formula corresponds to the institutions-augmented model. The regression equations can be estimated in two versions: unrestricted and restricted. Equation (21), for example, shows that the sum of the coefficients of the variables $\ln s_{i}$ should be equal in absolute terms to the coefficient of the variable $\ln (n+a+\delta)$. However, a model that is estimated based on the real data need not share these properties. Hence, the regression equation that includes the variables $\ln s_{i}$ and $\ln (n+a+\delta)$ independently is known as the unrestricted model. When estimating this model, the sum of the coefficients of the variables $\ln s_{i}$ does not have to be equal in absolute value to the coefficient of $\ln (n+a+\delta)$. However, this equality will hold in the restricted version of the equation, where the explanatory variables $\ln s_{i}$ and $\ln (n$ $+a+\delta)$ are interrelated. The restricted model is obtained by subtracting $\ln (n+a+\delta)$ from each of the $\ln s_{i}$ variables. The details are presented in Table 1.

Table 1 is composed of three parts that represent the basic Solow model, the Mankiw-Romer-Weil model and the institutions-augmented Solow model in that order. The first two rows specify the number of inputs and the production function, and the next two rows present the regression equations that are estimated using the ordinary least squares (OLS) method for the unrestricted and restricted model. In addition, the next row relates the regression coefficients with the production function parameters according to equations (11), (12) and (21). Finally, the last row shows the way in which we estimate the production function parameters.

Before conducting our calculations, we have to impose one additional assumption. Equations (11), (12) and (21) include (inter alia) the technical progress and the depreciation rate. However, it is impossible to obtain real values for these parameters in our sample of countries. Hence, we assume that the sum of the rate of technical progress and the depreciation rate equals 0.05 (i.e., 5\%), which is a common assumption in such analyses and should not lower the reliability of the results with respect to the aim of our study (see, e.g., Mankiw, Romer, Weil, 1992; Murthy, Chien, 1997; Murthy, Upkolo, 1999; Nonneman, Vanhoudt, 1996).

The variable denoted by $y$ in Table 1 represents the current level of economic development. We consider the economic development as a proxy for the GDP per capita at purchasing power parity (PPP) (in international US dollars); this variable is taken from the Penn World Table (PWT) 7.0 database (Heston, Summers, \& Aten, 2011). To be robust to business cycles and especially the global crisis of 2009 (Śledziewska, Witkowski (2012) analyze some of its effects), we define economic development as the average GDP per capita at PPP for the years 2005-2009, that is, over five years. This definition allows us to pass over the recession that in some countries, e.g., the Baltic states, led to a large drop in the GDP. Hence, ln $y$ is the natural logarithm of the five-year average GDP per capita.

The explanatory variable $s_{K}$ is the average investment rate in physical capital for the period 1994-2009. The investment rate is measured as the ratio of the gross fixed capital formation to the GDP and is taken 
Table 1. The determinants of GDP per capita according to various versions of the Solow model

\begin{tabular}{ll}
\hline \hline & The basic Solow model \\
\hline \hline Number of inputs: & 1 (physical capital) \\
\hline Production function: & $Y=K^{\alpha}(A L)^{1-\alpha}$ or per unit of effective labor: $y=k^{\alpha}$ \\
\hline Unrestricted model: & $\ln y=\alpha_{0}+\alpha_{1} \ln s_{K}+\alpha_{2} \ln (n+0.05)$ \\
\hline Restricted model: & $\ln y=\alpha_{0}+\alpha_{1}\left(\ln s_{K}-\ln (n+0.05)\right)$ \\
\hline Regression coefficients: & $\alpha_{0}-$ a constant, $\quad \alpha_{1}=\frac{\alpha}{1-\alpha}, \quad \alpha_{2}=-\frac{\alpha}{1-\alpha}$ \\
\hline
\end{tabular}

Estimation of the parameters

physical capital's share in the income: $\quad \hat{\alpha}=\frac{\alpha_{1}}{1+\alpha_{1}}$

The Mankiw-Romer-Weil model (the human capital-augmented Solow model)

\begin{tabular}{ll}
\hline \hline Number of inputs: & 2 (physical capital, human capital) \\
\hline Production function: & $Y=K^{\alpha} H^{\beta}(A L)^{1-\alpha-\beta}$ or per unit of effective labor: $y=k^{\alpha} h^{\beta}$ \\
\hline Unrestricted model: & $\ln y=\alpha_{0}+\alpha_{1} \ln s_{K}+\alpha_{2} \ln s_{H}+\alpha_{3} \ln (n+0.05)$ \\
\hline Restricted model: & $\ln y=\alpha_{0}+\alpha_{1}\left(\ln s_{K}-\ln (n+0,05)\right)+\alpha_{2}\left(\ln s_{H}-\ln (n+0.05)\right)$ \\
\hline Regression coefficients: & $\alpha_{0}-$ a constant, $\alpha_{1}=\frac{\alpha}{1-\alpha-\beta}, \quad \alpha_{2}=\frac{\beta}{1-\alpha-\beta}, \frac{\alpha}{-\alpha-\beta}$ \\
\hline Estimation of the parameters & $\hat{\alpha}=\frac{\alpha_{1}}{1+\alpha_{1}+\alpha_{2}}$ \\
$\quad$ physical capital's share in the income: & $\hat{\beta}=\frac{\alpha_{2}}{1+\alpha_{1}+\alpha_{2}}$ \\
\hline
\end{tabular}

The institutions-augmented Solow model

\begin{tabular}{ll}
\hline \hline Number of inputsa: & 3 (physical capital, human capital, institutions) \\
\hline Production function: & $Y=K^{\alpha} H^{\beta}(A L)^{1-\alpha-\beta} Q^{\zeta}$ or per unit of effective labor: $y=k^{\alpha} h^{\beta} Q^{\zeta}$ \\
\hline Unrestricted model: & $\ln y=\alpha_{0}+\alpha_{1} \ln s_{K}+\alpha_{2} \ln s_{H}+\alpha_{3} \ln Q+\alpha_{4} \ln (n+0.05)$ \\
\hline Restricted model: & $\ln y=\alpha_{0}+\alpha_{1}\left(\ln s_{K}-\ln (n+0,05)\right)+\alpha_{2}\left(\ln s_{H}-\ln (n+0,05)\right)+\alpha_{3} \ln Q$ \\
\hline Regression coefficients: & $\alpha_{0}-$ a constant, $\alpha_{1}=\frac{\alpha}{1-\alpha-\beta}, \alpha_{2}=\frac{\beta}{1-\alpha-\beta}, \alpha_{3}=\frac{\zeta}{1-\alpha-\beta}, \alpha_{4}=-\frac{\alpha+\beta}{1-\alpha-\beta}$ \\
\hline Estimation of the parameters & $\hat{\alpha}=\frac{\alpha_{1}}{1+\alpha_{1}+\alpha_{2}}$ \\
physical capital's share in income: & $\hat{\beta}=\frac{\alpha_{2}}{1+\alpha_{1}+\alpha_{2}}$ \\
& $\hat{\zeta}=\alpha_{3}(1-\hat{\alpha}-\hat{\beta})$ \\
human capital's share in income: & \\
&
\end{tabular}

Notes:

a Apart from the effective labor. 
from the World Development Indicators (WDI) database (World Bank, 2011a).

The growth rate of the population $(n)$ is the difference between the natural logarithms of the population levels in 2009 and 1994 divided by 15 (the number of years between 1994 and 2009). This variable comes from the WDI.

The investment rate in human capital is not so easy to find, as there is no unique and commonly accepted measure of human capital. In empirical studies, many indices are used depending on the research methodology and data availability. For the purposes of our analysis, we estimate the variable $s_{H}$ by various methods to choose the best variant. The investment rate in human capital has been calculated in eight distinct variants:

- public spending on education (\% of GDP) - edu;

- secondary school enrollment (\% gross) - enrol_sec;

- tertiary school enrollment (\% gross) - enrol_ter;

- average years of tertiary schooling (age 25+) - years_ter;

- average years of total schooling (age 25+) - years_tot;

- percentage of the population (age 25+) that has completed a tertiary education - pop_ter;

- duration of compulsory education (years) - dur_comp;

- labor force with a tertiary education (\% of total) - lab_ter.

All the above variables have been calculated as arithmetic averages for the period 1994-2009 (in the event of missing values, the average covers a shorter period). The human capital figures are taken from the World Bank's WDI (the variables edu, enrol_sec, enrol_ter and lab_ter) or Education Statistics (the variable dur_comp) databases, or from the Barro-Lee dataset, which is available in the Education Statistics databank (the variables years_ter, years_tot and pop_ter) (World Bank, 2011a; 2011b).

With regard to institutions, the selection of variables is even more difficult. There is no widely accepted view on how to measure institutions. Moreover, some types of institutions cannot be quantified at all. In this research, we use six qualitative indicators that represent the following areas of the institutional environment: democracy, the governance, economic freedom and the ease of doing business. More specifically, we consider the following indicators (Economist Intelligence Unit, 2011; Fraser Institute, 2011; Freedom House,
2011; Heritage Foundation, 2011; World Bank, 2011c; 2011d):

- democracy index (2008; Economist Intelligence Unit) - dem_eiu;

- democracy index with respect to political rights (avg. for 1994-2009; Freedom House) - dem_pr;

- governance indicator (avg. for 1996, 1998, 2000, 2002-2009; World Bank) - gov;

- index of economic freedom (avg. for 1995-2009; Heritage Foundation) - ef_hf;

- index of economic freedom (avg. for 1995, 2000 -2008; Fraser Institute) - ef_fi;

- ease of doing business index (2009; World Bank) - doing_b.

Many of the above indices are the most commonly used institutional indicators in the empirical studies on economic growth (see the review of the literature presented in section 2). We tried to calculate them as averages for the period 1994-2009. However, many of the variables are not available for all these years. Nevertheless, we decided to choose the institutional indicator even if it is only available for one year (e.g., dem_eiu or doing_b). This decision is justified because institutions do not change much during a short time period, and hence, we may assume that the value for the last available year is also valid for the previous years.

The democracy index published by the Economist Intelligence Unit is a qualitative variable that ranges between 0 and 10 , where 10 means the best outcome was achieved. This index is based on the ratings for 60 indicators grouped into five categories: the electoral process and pluralism, the functioning of government, political participation, the political culture and civil liberties. The overall democracy index is the simple average of these five category indexes.

The democracy variable that was taken from the Freedom House measures the political rights. Following the methodology of Barro and Sala-i-Martin (2003, p. 528), we treat the political rights as the proxy for the level of democracy, and we call it the democracy index. (Freedom House publishes two indices: political rights and civil liberties.) The original indicator ranges between 1 and 7 , where 1 means the best outcome was achieved.

The World Bank publishes data on governance that cover six areas: voice and accountability, political stability and the absence of violence, government ef- 
fectiveness, the regulatory quality, the rule of law and the control of corruption. The governance indicator included in our analysis has been calculated by us as the simple arithmetic average of these six component indices. The indicator ranges between -2.5 and +2.5 , and a higher value corresponds to a better outcome.

The Heritage Foundation index of economic freedom is an arithmetic average of the following 10 category indices: business freedom, trade freedom, fiscal freedom, government spending, monetary freedom, investment freedom, financial freedom, property rights, freedom from corruption and labor freedom. All these indicators range between 0 and 100, and a higher value is the desirable outcome because it represents a greater scope of economic freedom.

Another index of economic freedom is compiled by the Fraser Institute. It is a qualitative variable composed of five indicators: (a) the size of government, (b) the legal structure and security of property rights, (c) the access to sound money, (d) the freedom to trade internationally, (e) the regulation of credit, labor and business. This variable ranges between 0 and 10 , and a higher outcome represents greater economic freedom.

The ease of doing business index measures a country's worldwide rank (with first place being the best). A good outcome means that the regulatory environment is conducive to business operations. This indicator is the average of the component indicators that cover the following areas: starting a business, dealing with construction permits, registering property, obtaining credit, protecting investors, paying taxes, trading across borders, enforcing contracts and closing a business.

As demonstrated, the above institutional indicators take values from different scales. Thus, for comparability purposes, all of them have been recalculated by us into the $0-100$ scale, where 100 represents the best (most desirable) outcome.

\section{Some empirics on human capital accumulation and the quality of institutions}

In this section, we verify the relationships among the variables that are tested in our study using a number of econometric techniques. First, we analyze the mutual correlation of some explanatory variables. Then, we test the relationship between the quality of the institutional environment and the level of economic development.

Table 2 shows the correlation matrix between all eight of the human capital measures. As demonstrated, our initial selection of these variables is quite good. Almost all of the correlations are statistically significant (insignificance appears only twice), which means that all of the selected variables perform very well in measuring the investment in (or the stock of) human capital. The countries that are abundant in human capital have on average higher values of all of the variables.

However, for the sake of conciseness, for further analysis we choose one variable that represents human capital: the tertiary school enrollment ratio (enrol_ter). The selection of this variable is based on two criteria.

The first criterion is the economic significance of this variable. In our opinion, the years of schooling, the percentage of the population that has completed a given level of education or the intensity of school attendance are better proxies for the human capital stock (or investment) than the public expenditure on education $(e d u)$. Our opinion was formed for two reasons: first, public spending does not include private expenditures, which in some countries (e.g., the United States) play an important role in human capital accumulation; second, the level of public expenditure does not tell us anything about the effectiveness of investment outlays. That is why we decided to ignore the $e d u$ variable in our analysis. Moreover, the correlation matrix indicates that although $e d u$ is statistically significant, it is not strongly correlated with the remaining variables (due to low values of the coefficients).

The second criterion of our selection is the statistical significance. All the variables except $e d u$ are highly mutually correlated (the correlation coefficients even approach 0.8-0.9). However, because lab_ter is only available for a relatively small number of countries, it should be excluded. From the rest of the variables, we select enrol_ter (the tertiary school enrolment ratio) for further analysis, and we take into account a slightly arbitrary choice but also a high number of observations (153 is the maximum possible number of observations).

Now, let us analyze the results for the second group of variables, that is, the institutional indicators. Table 3 presents the respective correlation matrix.

It turns out that all of the selected institutional measures are strongly and significantly correlated with 
Table 2. The correlation coefficients between various measures of human capital

\begin{tabular}{|c|c|c|c|c|c|c|c|c|}
\hline & $\ln (e d u)$ & In(enrol_sec) & In(enrol_ter) & In(years_ter) & In(years_tot) & In(pop_ter) & In(dur_comp) & In(lab_ter) \\
\hline $\ln (e d u)$ & $\begin{array}{l}1.0000 \\
(153)\end{array}$ & $\begin{array}{l}0.2445^{* * *} \\
(153)\end{array}$ & $\begin{array}{l}0.1620^{* *} \\
(153)\end{array}$ & $\begin{array}{l}0.0655 \\
(129)\end{array}$ & $\begin{array}{l}0.1741^{* *} \\
(129)\end{array}$ & $\begin{array}{l}0.0626 \\
(129)\end{array}$ & $\begin{array}{l}0.2605^{* * *} \\
(153)\end{array}$ & $\begin{array}{l}0.1520^{*} \\
(93)\end{array}$ \\
\hline In(enrol_sec) & $\begin{array}{l}0.2445^{* * *} \\
(153)\end{array}$ & $\begin{array}{l}1.0000 \\
(153)\end{array}$ & $\begin{array}{l}0.8609^{* * *} \\
(153)\end{array}$ & $\begin{array}{l}0.8183^{* * *} \\
(129)\end{array}$ & $\begin{array}{l}0.8506^{* * *} \\
(129)\end{array}$ & $\begin{array}{l}0.7941^{* * *} \\
(129)\end{array}$ & $\begin{array}{l}0.5650^{* * *} \\
(153)\end{array}$ & $\begin{array}{l}0.7695^{* * *} \\
(93)\end{array}$ \\
\hline In(enrol_ter) & $\begin{array}{l}0.1620^{* *} \\
(153)\end{array}$ & $\begin{array}{l}0.8609^{* * *} \\
(153)\end{array}$ & $\begin{array}{l}1.0000 \\
(153)\end{array}$ & $\begin{array}{l}0.8797^{* * *} \\
(129)\end{array}$ & $\begin{array}{l}0.7611^{* * *} \\
(129)\end{array}$ & $\begin{array}{l}0.8567^{* * *} \\
(129)\end{array}$ & $\begin{array}{l}0.5097^{* * *} \\
(153)\end{array}$ & $\begin{array}{l}0.7784^{* * *} \\
(93)\end{array}$ \\
\hline In(years_ter) & $\begin{array}{l}0.0655 \\
(129)\end{array}$ & $\begin{array}{l}0.8183^{* * *} \\
(129)\end{array}$ & $\begin{array}{l}0.8797^{* * *} \\
(129)\end{array}$ & $\begin{array}{l}1.0000 \\
(129)\end{array}$ & $\begin{array}{l}0.8104^{* * *} \\
(129)\end{array}$ & $\begin{array}{l}0.9851^{* * *} \\
(129)\end{array}$ & $\begin{array}{l}0.4880^{* * *} \\
(129)\end{array}$ & $\begin{array}{l}0.8208^{* * *} \\
(84)\end{array}$ \\
\hline In(years_tot) & $\begin{array}{l}0.1741^{* *} \\
(129)\end{array}$ & $\begin{array}{l}0.8506^{* * *} \\
(129)\end{array}$ & $\begin{array}{l}0.7611^{* * *} \\
(129)\end{array}$ & $\begin{array}{l}0.8104^{* * *} \\
(129)\end{array}$ & $\begin{array}{l}1.0000 \\
(129)\end{array}$ & $\begin{array}{l}0.7893^{* * *} \\
(129)\end{array}$ & $\begin{array}{l}0.5022^{* * *} \\
(129)\end{array}$ & $\begin{array}{l}0.7069^{* * *} \\
(84)\end{array}$ \\
\hline In(pop_ter) & $\begin{array}{l}0.0626 \\
(129)\end{array}$ & $\begin{array}{l}0.7941^{* * *} \\
(129)\end{array}$ & $\begin{array}{l}0.8567^{* * *} \\
(129)\end{array}$ & $\begin{array}{l}0.9851^{* * *} \\
(129)\end{array}$ & $\begin{array}{l}0.7893^{* * *} \\
(129)\end{array}$ & $\begin{array}{l}1.0000 \\
(129)\end{array}$ & $\begin{array}{l}0.4658^{* * *} \\
(129)\end{array}$ & $\begin{array}{l}0.7880^{* * *} \\
(84)\end{array}$ \\
\hline $\begin{array}{l}\text { In(dur_ } \\
\text { comp) }\end{array}$ & $\begin{array}{l}0.2605^{* * *} \\
(153)\end{array}$ & $\begin{array}{l}0.5650^{* * *} \\
(153)\end{array}$ & $\begin{array}{l}0.5097^{* * *} \\
(153)\end{array}$ & $\begin{array}{l}0.4880^{* * *} \\
(129)\end{array}$ & $\begin{array}{l}0.5022^{* * *} \\
(129)\end{array}$ & $\begin{array}{l}0.4658^{* * *} \\
(129)\end{array}$ & $\begin{array}{l}1.0000 \\
(153)\end{array}$ & $\begin{array}{l}0.4793^{* * *} \\
(93)\end{array}$ \\
\hline In(lab_ter) & $\begin{array}{l}0.1520^{*} \\
(93)\end{array}$ & $\begin{array}{l}0.7695^{* * *} \\
(93)\end{array}$ & $\begin{array}{l}0.7784^{* * *} \\
(93)\end{array}$ & $\begin{array}{l}0.8208^{* * *} \\
(84)\end{array}$ & $\begin{array}{l}0.7069^{* * *} \\
(84)\end{array}$ & $\begin{array}{l}0.7880^{* * *} \\
(84)\end{array}$ & $\begin{array}{l}0.4793^{* * *} \\
(93)\end{array}$ & $\begin{array}{l}1.0000 \\
(93)\end{array}$ \\
\hline
\end{tabular}

Notes:

The number of observations (countries) is in brackets.

*** The correlation is significant at the $1 \%$ level.

** The correlation is significant at the $10 \%$ level.

* The correlation is significant at the $15 \%$ level.

Table 3. The correlation coefficients between various measures of the institutional environment

\begin{tabular}{|c|c|c|c|c|c|c|}
\hline & In(dem_eiu) & In(dem_pr) & $\ln (g \circ v)$ & $\ln \left(e f \_h f\right)$ & $\ln \left(e f \_f i\right)$ & In(doing_b) \\
\hline In(dem_eiu) & $1.0000(143)$ & $0.7230^{* * *}(143)$ & $0.7974^{* * *}(143)$ & $0.6770^{* * *}(142)$ & $0.6776^{* * *}(110)$ & $0.6117^{* * *}(140)$ \\
\hline In(dem_pr) & $0.7230^{* * *}(143)$ & 1.0000 (153) & $0.5471^{* * *}(153)$ & $0.6025^{* * *}(148)$ & $0.4438^{* * *}(112)$ & $0.2764^{* * *}(150)$ \\
\hline $\ln ($ gov) & $0.7974^{* * *}(143)$ & $0.5471^{* * *}(153)$ & 1.0000 (153) & $0.8106^{* * *}(148)$ & $0.8316^{* * *}(112)$ & $0.6643^{* * *}(150)$ \\
\hline $\ln \left(e f \_h f\right)$ & $0.6770^{* * *}(142)$ & $0.6025^{* * *}(148)$ & $0.8106^{* * *}(148)$ & 1.0000 (148) & $0.8763^{* * *}(111)$ & $0.6012^{* * *}(145)$ \\
\hline $\ln \left(e f \_f i\right)$ & $0.6776^{* * *}(110)$ & $0.4438^{* * *}(112)$ & $0.8316^{* * *}(112)$ & $0.8763^{* * *}(111)$ & $1.0000(112)$ & $0.6705^{* * *}(111)$ \\
\hline In(doing_b) & $0.6117^{* * *}(140)$ & $0.2764^{* * *}(150)$ & $0.6643^{* * *}(150)$ & $0.6012^{* * *}(145)$ & $0.6705^{* * *}(111)$ & $1.0000(150)$ \\
\hline
\end{tabular}

Notes:

The number of observations (countries) is in brackets.

*** The correlation is significant at the $1 \%$ level. 



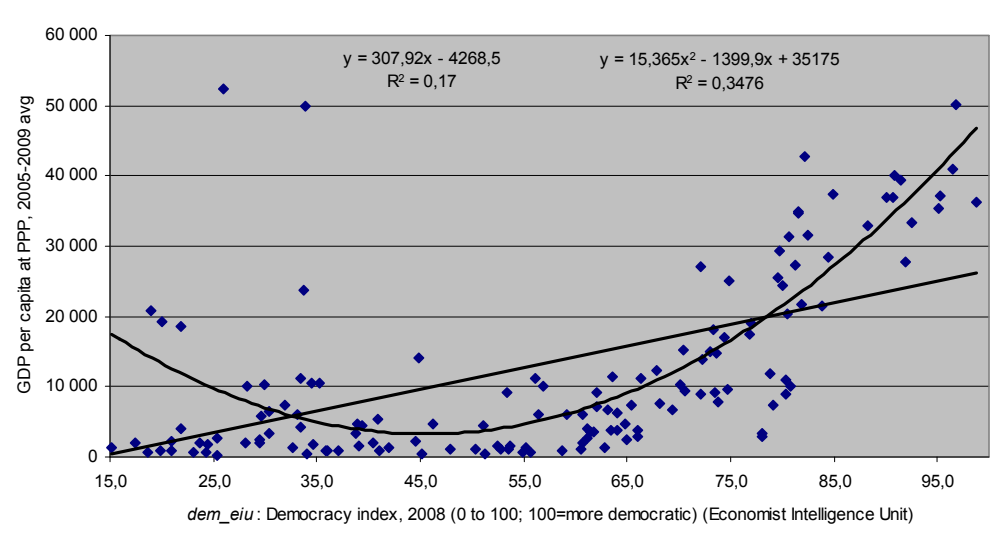

Figure 2. The relationship between the level of democracy and the economic development Note: 143 countries.

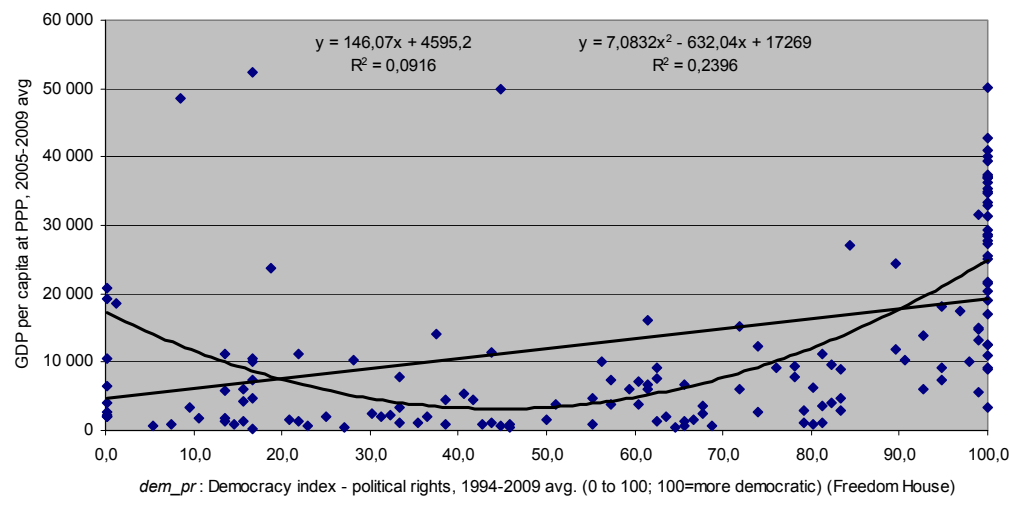

Figure 3. The relationship between the level of democracy and the economic development Note: 153 countries.

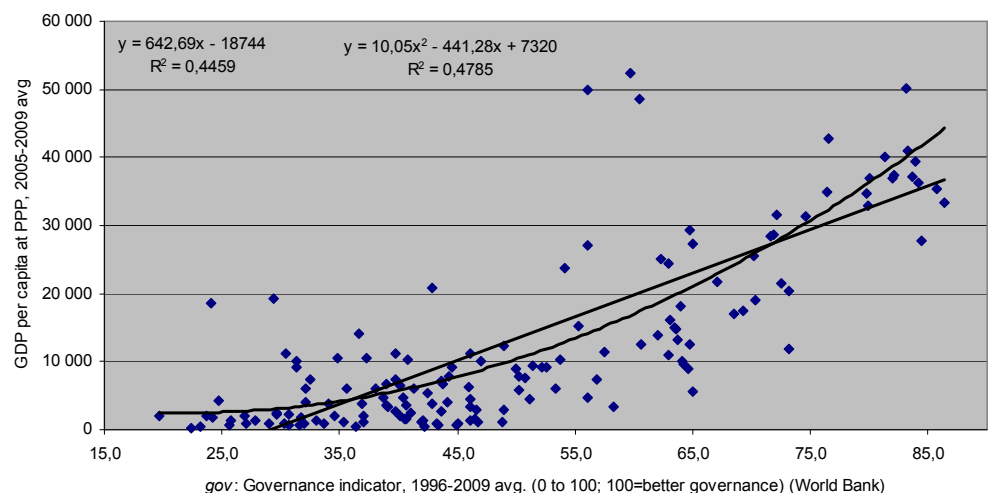

Figure 4. The relationship between the quality of governance and the economic development Note: 153 countries. 


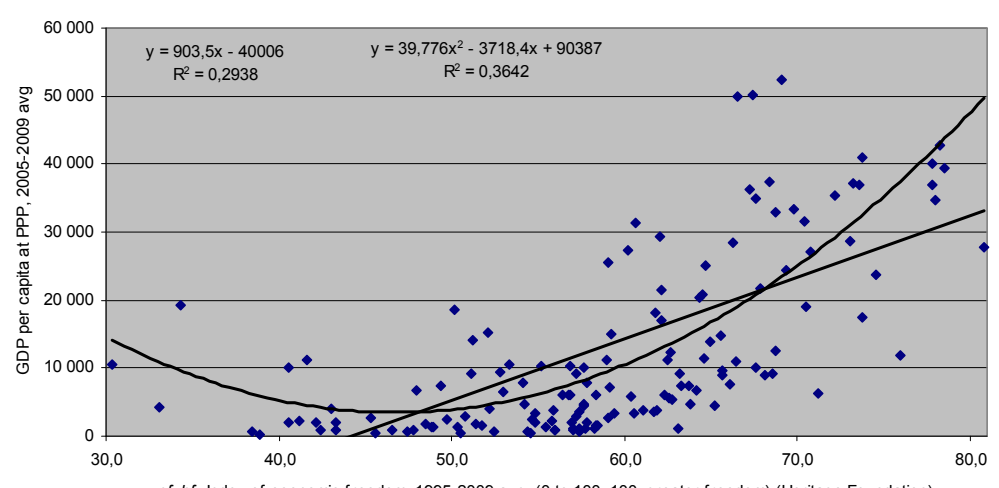

ef_hf: Index of economic freedom, 1995-2009 avg. (0 to 100; 100=greater freedom) (Heritage Foundation)

Figure 5. The relationship between economic freedom and the economic development

Note: 148 countries.

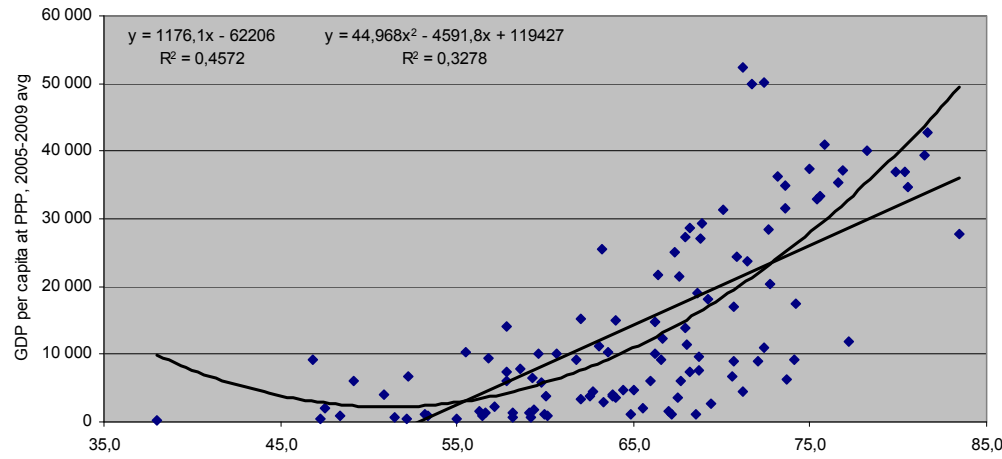

ef $f i$ : Index of economic freedom, 1995-2008 avg. (0 to 100; 100=greater freedom) (Fraser Institute)

Figure 6. The relationship between economic freedom and the economic development

Note: 112 countries.

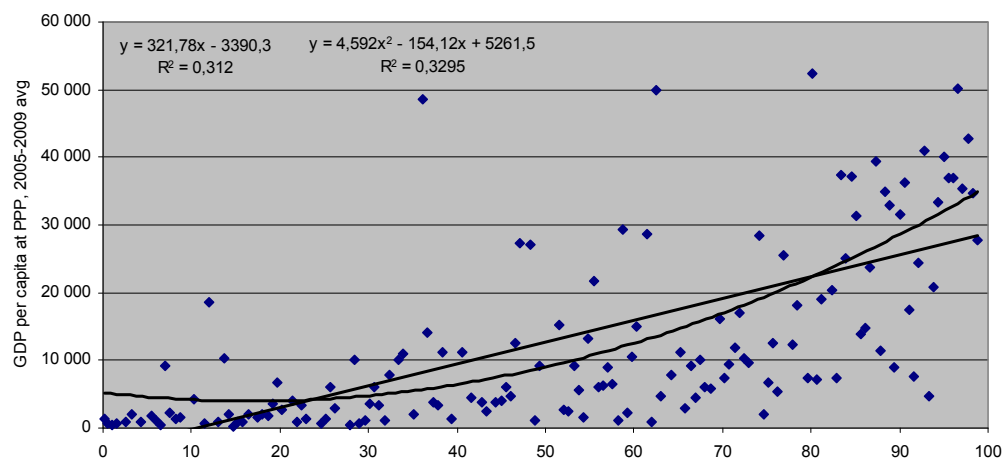

doing_b : Ease of doing business index, 2009 ( 0 to 100; 100=most business-friendly regulations) (World Bank)

Figure 7. The relationship between the ease of doing business and the economic development Note: 150 countries. 
these findings are not spurious. Instead, they result from the fact that many countries of the Arab world (Bahrain, Kuwait, Qatar, Saudi Arabia and the United Arab Emirates) are not democratic but still record high income levels. This characteristic exists because these countries earn a large part of their income from oil exports. In such a case, a high GDP per capita can be achieved despite a non-democratic environment.

The model that shows an impact of the quality of governance on economic development has a very good fit to the empirical data in both the linear and nonlinear approaches. The $R^{2}$ coefficient equals $44.6 \%$ for a linear equation and $47.9 \%$ for a nonlinear one. These high $R$-squares suggest that differences in the quality of governance have enormous power in explaining worldwide differences in economic development. It turns out that almost $50 \%$ of the differences in the income levels can be attributed to differences in the quality of governance. Because the data are available for all the countries that are included in our sample (153), they are not spurious. Thus, good governance matters and is important for economic growth. In addition, positive outcomes in terms of voice and accountability, political stability, the absence of violence, government effectiveness, the quality of regulations and the control of corruption all have a significant impact on economic development.

The quality of governance is closely linked with economic freedom. Indeed, this variable is also important in stimulating GDP. The two analyzed indices of economic freedom (which were taken from the Heritage Foundation and the Fraser Institute) reveal a strong and positive correlation with the per capita income. Both linear and nonlinear models fit the empirical points well with $R^{2}$ coefficients at the levels of 29.4\% and $36.4 \%$ for the Heritage Foundation index and $45.7 \%$ and $32.8 \%$ for the Fraser Institute indicator, respectively. The nonlinear model is of a similar quality for both indices, whereas the linear equation gives better results in the case of the Fraser Institute index. Regardless of the specification, the differences in economic freedom explain approximately $30-40 \%$ of the differences in economic development. This result is not spurious because more economically free countries have the necessary preconditions for being rich than countries with low scopes of economic freedom.

The last index is the ease of doing business, and it also confirms the importance of high-quality institutions in fostering economic development. The countries that have more business-friendly regulations are on average richer than the remaining ones. The econometric results suggest that differences in the ease of doing business explain approximately $30 \%$ of the differences in the level of economic development among the countries of the world. These results hold for both the linear and nonlinear models.

In summation, our analysis clearly gives important and interesting advice to politicians and policy makers. Each government should act to improve all the areas of the local institutional environment, especially the quality of governance, the economic freedom and the ease of doing business. All these variables explain an enormous part of the worldwide differences in income levels and are necessary for economic development. The components of our institutional indicators specify the exact areas that should be improved and strengthened by governments. Without positive changes in the institutional environment, it is very difficult for societies to achieve strong and sustainable economic growth. To enrich a country, its policy makers should focus on those institutional reforms that affect the GDP via supply-side and demand-side determinants.

\section{Empirical verification of the institutions-augmented Solow model}

We verify the institutions-augmented Solow model using the equations presented in Table 1. According to this model, the level of economic development depends on the investment rates in physical and human capital, the quality of institutions and the growth rate of the population. The relationships between economic development and both the capital accumulation and the institutional environment are obviously positive, while the link with the population growth should be negative. To check the robustness of the results, we verify not only the institutions-augmented Solow model but also the standard Solow model and the MankiwRomer-Weil model.

Table 4 illustrates the empirical estimation of the equations presented in Table 1. Panel $a$ represents unrestricted regressions, whereas panel $b$ includes restricted variants. The respective columns of the table concern the three tested types of the model. The basic Solow model includes one type of capital as the explan- 
Table 4. The regression results for the determinants of GDP per capita

\section{(a) Unrestricted models}

\begin{tabular}{|c|c|c|c|}
\hline & The Solow model & The Mankiw-Romer-Weil model & $\begin{array}{c}\text { The institutions-augmented } \\
\text { Solow model }\end{array}$ \\
\hline \multirow[t]{2}{*}{$\ln s_{K}$} & 1.253 & 0.877 & 0.539 \\
\hline & $t=3.63 ; \quad p=0.000$ & $t=3.83 ; \quad p=0.000$ & $t=2.80 ; \quad p=0.006$ \\
\hline \multirow[t]{2}{*}{$\ln s_{H}$} & & 0.908 & 0.669 \\
\hline & & $t=14.01 ; \quad p=0.000$ & $t=11.13 ; \quad p=0.000$ \\
\hline \multirow[t]{2}{*}{$\ln Q$} & & & 1.557 \\
\hline & & & $t=8.55 ; \quad p=0.000$ \\
\hline \multirow[t]{2}{*}{$\ln (n+0.05)$} & -2.378 & 1.240 & 1.244 \\
\hline & $t=-4.61 ; \quad p=0.000$ & $t=2.91 ; \quad p=0.004$ & $t=3.55 ; \quad p=0.001$ \\
\hline \multirow[t]{2}{*}{ constant } & -1.618 & 7.084 & 2.773 \\
\hline & $t=-0.97 ; \quad p=0.333$ & $t=5.62 ; \quad p=0.000$ & $t=2.41 ; \quad p=0.017$ \\
\hline$R^{2}$ adj. & $19.7 \%$ & $65.1 \%$ & $76.5 \%$ \\
\hline$R^{2}$ & $20.8 \%$ & $65.8 \%$ & $77.1 \%$ \\
\hline$n$ & 153 & 153 & 153 \\
\hline$F$ & $F=19.65 ; \quad p=0.000$ & $F=95.59 ; \quad p=0.000$ & $F=124.65 ; \quad p=0.000$ \\
\hline \multicolumn{4}{|c|}{ Estimated values of the parameters } \\
\hline$a$ & \multirow[t]{3}{*}{0.556} & 0.315 & 0.244 \\
\hline$\beta$ & & 0.326 & 0.303 \\
\hline$\zeta$ & & & 0.705 \\
\hline \multicolumn{4}{|c|}{ Estimated values of the parameters - the average for three models } \\
\hline \multicolumn{4}{|c|}{$a=0.372 ; \quad \beta=0.315 ; \quad \zeta=0.705$} \\
\hline
\end{tabular}

\section{(b) Restricted models}

\begin{tabular}{|c|c|c|c|}
\hline & The Solow model & The Mankiw-Romer-Weil model & $\begin{array}{l}\text { The institutions-augmented } \\
\text { Solow model }\end{array}$ \\
\hline \multirow[t]{2}{*}{$\ln s_{K}-\ln (n+0.05)$} & 1.624 & 0.286 & 0.036 \\
\hline & $t=5.99 ; \quad p=0.000$ & $t=1.26 ; \quad p=0.208$ & $t=0.19 ; \quad p=0.846$ \\
\hline \multirow[t]{2}{*}{$\ln s_{H}-\ln (n+0.05)$} & & 0.696 & 0.477 \\
\hline & & $t=11.82 ; \quad p=0.000$ & $t=8.78 ; \quad p=0.000$ \\
\hline \multirow[t]{2}{*}{$\ln Q$} & & & 1.715 \\
\hline & & & $t=8.68 ; \quad p=0.000$ \\
\hline \multirow[t]{2}{*}{ constant } & -0.670 & 3.324 & -0.639 \\
\hline & $t=-0.42 ; \quad p=0.672$ & $t=2.79 ; \quad p=0.006$ & $t=-0.59 ; \quad p=0.553$ \\
\hline$R^{2}$ adj. & $18.7 \%$ & $57.6 \%$ & $71.7 \%$ \\
\hline$R^{2}$ & $19.2 \%$ & $58.2 \%$ & $72.2 \%$ \\
\hline$n$ & 153 & 153 & 153 \\
\hline$F$ & $F=35.88 ; \quad p=0.000$ & $F=104.25 ; \quad p=0.000$ & $F=129.03 ; \quad p=0.000$ \\
\hline \multicolumn{4}{|c|}{ Estimated values of the parameters } \\
\hline$a$ & \multirow[t]{3}{*}{0.619} & 0.144 & 0.024 \\
\hline$\beta$ & & 0.351 & 0.315 \\
\hline$\zeta$ & & & 1.133 \\
\hline \multicolumn{4}{|c|}{ Estimated values of the parameters - the average for three models } \\
\hline \multicolumn{4}{|c|}{$a=0.262 ; \quad \beta=0.333 ; \quad \zeta=1.133$} \\
\hline
\end{tabular}


atory variable: $\ln s_{K}$; the Mankiw-Romer-Weil model includes two such variables: $\ln s_{K}$ and $\ln s_{H^{\prime}}$ lastly, the institutions-augmented Solow model includes $\ln s_{K}, \ln$ $s_{H}$ and the institutional indicator $\ln Q$. The top rows of the table show the regression coefficients with $t$-statistics and $p$-values. Below, there are $R$-squares (both standard and adjusted), the number of observations $(n)$ and the results of the $F$ test. The bottom part presents the estimated parameters of the production function. The last row includes the average values of these parameters (in the case of $\beta$ and $\zeta$, the average is based on a limited number of equations).

The data in Table 4 indicate that all the types of the Solow model perform extraordinarily well in explaining worldwide income-level differences. This property particularly holds for the unrestricted regressions. For each unrestricted equation, all the coefficients (except those for the population growth) have the correct (expected) sign and are statistically significant. Thus, our study has clearly confirmed that the accumulation of both types of capital and the quality of the institutional environment are positively related with the level of economic development. These results are very valuable and seem to be consistent with reality.

Referring to the unrestricted regressions, which give more reliable results in our opinion, the investment rate in physical capital positively affects the creation of GDP. In all the regression equations, this variable is highly significant with a $p$-value less than 0.01 . The countries that devote large parts of their income to investments are on average richer than those countries that have low investment rates.

Similarly, human capital accumulation also plays an important role in enhancing economic development. In both considered models, the human capital variable is extraordinarily significant (with $t$-statistics exceeding 10 and $p$-values of 0.000). Such an outcome is not spurious and emphasizes the enormous impact of human capital formation on economic development. As a result, countries that want to be rich should invest in education (in both qualitative and quantitative terms); of course, they should invest not only in tertiary education, which is included in the regression equations, but also in secondary and primary education. Our study shows that human capital is the most important variable that is responsible for economic development. Indeed, without a sufficient stock of human capital, it is very hard for a society to develop institutions that are favorable for economic development.

The institutions-augmented Solow model confirms a positive and significant impact of the quality of institutions, which is measured by the governance indicator on economic development. The variable $\ln Q$ that enters the third model has a positive coefficient with a $p$-value of 0.000 . This result confirms our earlier results on the crucial role of institutions in stimulating economic development. There are very few rich countries with unfriendly institutions. The significance of institutions is comparable to the importance of the human capital accumulation.

It is worth comparing the $R^{2}$ coefficients of the respective models, and the results are very interesting. We focus on adjusted $R$-squares. According to the basic Solow model, the differences in the investment rate (as well as the population growth) explain $20 \%$ of the differences in the worldwide income levels, which is not particularly revealing. However, if we introduce human capital, this figure increases to $65 \%$. In other words, approximately $2 /{ }_{3}$ of the worldwide variety in GDP per capita can be explained by physical and human capital accumulation. This number rises further when we consider the institutions-augmented Solow model. Based on this model, the differences in physical capital, human capital and the quality of the institutional environment explain approximately $75 \%$ of the income differentiation among the world's countries.

The last figure is extremely high. Almost all of the worldwide development differences can be explained by three variables: physical capital accumulation, human capital accumulation and the quality of institutions. Hence, the institutions-augmented Solow model works very well; indeed, it is clearly superior to the basic Solow model, which only includes physical capital.

The above results imply that rich countries usually invest more in physical and human capital and have more developed institutions than poor countries. In other words, if a given country exhibits large investment rates, popular and high-quality education and a favorable institutional environment, then it is very likely that this country will be rich.

Of course, in interpreting these results we assume that the theoretical causal relationship between the explanatory variables and the level of economic development is as follows: the past values of the explanatory 
variables affect the current state of development. In reality, many macroeconomic relationships have mutual causality. Hence, it is worth noticing that rich countries also have greater opportunities to save, to invest in human capital and to have friendly regulations and institutions just because they are rich.

As we mentioned earlier, our main findings are based on unrestricted regression equations. However, it is worth adding that restricted models yield similar results to the unrestricted ones, with one exception. In restricted regressions, the coefficient of the variable that represents the interaction between the physical capital accumulation and the population growth turns out to be insignificant in both the Mankiw-RomerWeil model and the institutions-augmented Solow model. However, this result does not violate our earlier findings relative to the aim of the analysis. The coefficient of the institutional indicator in the restricted regression is still positive and highly significant, and hence, the quality of the institutional environment has a strong impact on the economic development. Second, according to the restricted regression, the differences in physical and human capital accumulation as well as the quality of institutions still explain more than $70 \%$ of the differences in worldwide income levels. This result confirms the good properties and empirical implications of the institutions-augmented Solow model.

Lastly, we estimate the production function. To be robust to different specifications of the set of explanatory variables, we calculate the final values of the parameters as arithmetic averages for various variants of the Solow model. According to the unrestricted regression equations, the labor share in the income ranges between 0.244 and 0.556 and has an average of 0.372 . The human capital share in the income is of a comparable level in both models (0.326 and 0.303), which yields a mean value of 0.315 . The institutional share amounts to 0.705 . Hence, the production function is the following:

$Y=K^{0.372} H^{0.315} L^{0.313} Q^{0.705}$

The exponent for $L$ is calculated as $1-\alpha-\beta$ (in line with the assumption of constant returns to $K, H$ and $L$ ).

The above formula seems to be reliable. The physical capital, human capital and labor shares in income are approximately $1 /{ }_{3}$ each, which is consistent with the empirical data for many countries. The institutions are more important in forming the GDP: the institutional elasticity of the output equals 0.705 .

The production function for restricted regressions can be derived in an analogous way. It has the following form:

$$
Y=K^{0.262} H^{0.333} L^{0.405} Q^{1.133}
$$

The powers of the measurable inputs ( $K, H$ and $L$ ) are at comparable levels to formula (24) (any discrepancies that appear are statistical). The only significant change concerns the institutional share. In production function (25), the institutional elasticity of output is significantly higher (1.133), which means that institutions play an even more important role in forming the GDP, as suggested by equation (24).

Overall, our study gives some valuable recommendations for politicians and policy makers. Governments should focus on improving the institutional environment, investing in education and stimulating investments. The empirical analysis clearly confirms that these factors are necessary for rapid economic development.

\section{Summary}

This study aims to assess to what extent the institutional environment is responsible for the worldwide differences in economic development. To answer this question, we build our own concept of the institutionsaugmented Solow model. Our analysis covers 153 countries and the period 1994-2009.

The empirical analysis confirms a large positive impact of the quality of the institutional environment on the level of economic development, which is measured by the 2005-2009 GDP per capita at PPP. The positive link has been evidenced for all six of the institutional indicators: two democracy indices, two indices of economic freedom, a governance indicator and the ease of doing business index. The relationship is linear, although some nonlinearities are present in the case of democracy.

Our own concept of the institutions-augmented Solow model fits the empirical data very well. The empirical verification of this model for 153 countries confirms that physical and human capital accumulation and the quality of the institutions, which are measured 
by the governance indicator, have a positive impact on the economic development. It turns out that the differences in physical capital, human capital and the institutional environment explain approximately $75 \%$ of the differences in economic development among the world's countries.

According to the institutions-augmented Solow mod$\mathrm{el}$, the production function that is consistent with unrestricted regressions is $Y=K^{0.372} H^{0.315} L^{0.313} Q^{0.705}$, whereas the function that is consistent with restricted regressions has the following form: $Y=K^{0.262} H^{0.333} L^{0.405} Q^{1.133}$, where $Q$ denotes the institutional indicator.

\section{References}

Asteriou, D., \& Siriopoulos, C. (2000). The Role of Political Instability in Stock Market Development and Economic Growth: The Case of Greece. Economic Notes, 29 (3), 355-374.

Asteriou, D., \& Price, S. (2001). Political Instability and Economic Growth: UK Time Series Evidence. Scottish Journal of Political Economy, 48 (4), 383-399.

Barro, R. J. (1996). Determinants of Economic Growth: A Cross-Country Empirical Study (Working Papers No. 5698). National Bureau of Economic Research.

Barro, R., \& Sala-i-Martin, X. (2003). Economic Growth (2nd ed.). Cambridge, MA: The MIT Press.

Białowolski, P., Kuszewski, T., \& Witkowski, B. (2010). Prognozy kombinowane wskaźników makroekonomicznych z użyciem danych z testów koniunktury [Business Survey Data in Forecasting Macroeconomic Indicators with Combined Forecasts]. Contemporary Economics, 4 (16), 41-58. Retrieved from http://we.vizja.pl/en/ issues/volume/4/issue/4\#art178

Chen, B., \& Feng, Y. (1996). Some Political Determinants of Economic Growth: Theory and Empirical Implications. European Journal of Political Econo$m y, 12$ (4), 609-627.

De Haan, J., \& Siermann, C. L. J. (1998). Further Evidence on the Relationship Between Economic Freedom and Economic Growth. Public Choice, 95 (3-4), 363-380.

De Haan, J., \& Sturm, J. E. (2000). On the Relationship Between Economic Freedom and Economic Growth. European Journal of Political Economy, 16 (2), 215-241.
Durham, J. B. (1999). Economic Growth and Political Regimes. Journal of Economic Growth, 4 (1), 81-111.

Economist Intelligence Unit (2011). The Democracy Index 2010: Democracy in Retreat. Availaible from www.eiu.com/public/topical_report.aspx? campaignid $=$ demo 2010

Feng, Y. (1997). Democracy, Political Stability and Economic Growth. British Journal of Political Science, 27 (3), 391-418.

Foss, N. J. (2012). Linking Ethics and Economic Growth: a Comment on Hunt. Contemporary Economics, 6 (3), 4-9.

Fosu, A. K. (2002). Political Instability and Economic Growth. Implications of Coup Events in Sub-Saharan Africa. American Journal of Economics and Sociology, 61 (1), 329-348.

Freedom House (2011). Freedom in the World. Retrieved from http://www.freedomhouse.org/ report-types/freedom-world

Gwartney, J., Lawson, R., \& Hall, J. (2012). Economic Freedom of the World 2010 Annual Report. Retrieved from http://www.freetheworld.com/2012/ EFW2012-complete.pdf

Heckelman, J. C., \& Stroup, M. D. (2000). Which Economic Freedoms Contribute to Growth?. Kyklos, 53 (4), 527-544.

Heritage Foundation (2011). 2011 Index of Economic Freedom. Retrieved from http://www.heritage. org/index/download

Heston, A., Summers, R., \& Aten, B. (2011, June). Penn World Table Version 7.0. Center for International Comparisons of Production, Income and Prices at the University of Pennsylvania. Retrieved from https://pwt.sas.upenn.edu/php_ site/pwt_index.php

Hunt, S. D. (2012a). Trust, Personal Moral Codes, and the Resource-Advantage Theory of Competition: Explaining Productivity, Economic Growth, and Wealth Creation. Contemporary Economics, 6 (2), 4-19.

Hunt, S. D. (2012b). Understanding the Drivers of Economic Growth: Grounding Endogenous Economic Growth Models in Resource-Advantage Theory. Contemporary Economics, 6 (4), 4-8.

Leblang, D. A. (1997). Political Democracy and Economic Growth: Pooled Cross-Sectional and TimeSeries Evidence. British Journal of Political Science, 27 (3), 453-466. 
Mankiw, N. G., Romer, D., \& Weil, D. N. (1992). A Contribution to the Empirics of Economic Growth. Quarterly Journal of Economics, 107 (2), 407-437.

Murthy, N. R. V., \& Chien, I. S. (1997). The Empirics of Economic Growth for OECD Countries: Some New Findings. Economics Letters, 55 (3), 425-429.

Murthy, N. R. V., \& Upkolo, V. (1999). A Test of the Conditional Convergence Hypothesis: Econometric Evidence from African Countries. Economics Letters, 65 (2), 249-253.

Nonneman, W., \& Vanhoudt, P. (1996). A Further Augmentation of the Solow Model and the Empirics of Economic Growth for OECD Countries. Quarterly Journal of Economics, 111 (3), 943-953.

Pitlik, H. (2002). The Path of Liberalization and Economic Growth. Kyklos, 55 (1), 57-79.

Plümper, T., \& Martin, C. W. (2003). Democracy, Government Spending, and Economic Growth: A Political-Economic Explanation of the Barro-Effect. Public Choice, 117 (1-2), 27-50.

Próchniak, M., \& Witkowski, B. (2012a). Konwergencja gospodarcza typu $\beta \mathrm{w}$ świetle bayesowskiego uśredniania oszacowań [Real b Convergence According to the Bayesian Averaging of Estimates]. Bank $i$ Kredyt, 43(2), 25-58.

Próchniak, M., \& Witkowski, B. (2012b). Bayesian Model Averaging in Modelling GDP Convergence with the Use of Panel Data. Roczniki Kolegium Analiz Ekonomicznych SGH, 26, 45-60.

Próchniak, M., \& Witkowski, B. (2013). Time Stability of the Beta Convergence among EU Countries: Bayesian Model Averaging Perspective. Economic Modelling, 30 (C), 322-333.

Rapacki, R. (Ed.) (2009). Wzrost gospodarczy w krajach transformacji: konwergencja czy dywergencja? [Economic Growth in Transition Countries: Real Convergence or Divergence?]. Warszawa: PWE.

Rapacki, R., \& Próchniak, M. (2009). The EU Enlargement and Economic Growth in the CEE New Member Countries (Economic Papers No. 367). European Economy.

Rapacki, R., \& Próchniak, M. (2010). Wpływ rozszerzenia Unii Europejskiej na wzrost gospodarczy i realną konwergencję krajów Europy ŚrodkowoWschodniej [The Impact of EU Enlargement on Economic Growth and Real Convergence of the
Central and Eastern European Countries]. Ekonomista, 4, 523-546.

Rivera-Batiz, F. L. (2002). Democracy, Governance, and Economic Growth: Theory and Evidence. Review of Development Economics, 6 (2), 225-247.

Scully, G. W. (2002). Economic Freedom, Government Policy and the Trade-Off Between Equity and Economic Growth. Public Choice, 113 (1-2), 77-96.

Solow, R. M. (1956). A Contribution to the Theory of Economic Growth. The Quarterly Journal of Economics, 70 (1), 65-94.

Sturm, J. E., Leertouwer, E., \& de Haan, J. (2002). Which Economic Freedoms Contribute to Growth? A Comment. Kyklos, 55 (3), 403-416.

Sulejewicz, A. (2009). Czynniki instytucjonalne w badaniach wzrostu gospodarczego krajów transformacji [Institutional Factors in Economic Growth Analyses of Transition Countries]. In R. Rapacki (Ed.), Wzrost gospodarczy w krajach transformacji: konwergencja czy dywergencja? [Economic Growth in Transition Countries: Real Convergence or Divergence?] (pp. 263-302). Warszawa: PWE.

Śledziewska, K., \& Witkowski, B. (2012). Światowy kryzys gospodarczy a handel międzynarodowy [Global Economic Crisis and International Trade]. Ekonomista, 4, 427-448.

Weede, E., \& Kämpf, S. (2002). The Impact of Intelligence and Institutional Improvements on Economic Growth. Kyklos, 55 (3), 361-380.

World Bank (2011a). World Data Bank: World Development Indicators. Retrieved May 1, 2011 from http:// databank.worldbank.org/data/databases.aspx

World Bank (2011b). World Data Bank: Education Statistics. Retrieved May 1, 2011 from http://databank.worldbank.org/data/databases.aspx

World Bank (2011c). World Data Bank: Worldwide Governance Indicators. Retrieved May 1, 2011 from http:// databank.worldbank.org/data/databases.aspx

World Bank (2011d). World Data Bank: Doing Business. Retrieved May 1, 2011 from http://databank. worldbank.org/data/databases.aspx

Wu, W., \& Davis, O. A. (1999). The Two Freedoms, Economic Growth and Development: An Empirical Study. Public Choice, 100 (1-2), 39-64. 
